\title{
Effect of chicken manure application and plant deleafing on soil characteristics and dwarf plantain (Musa AAB) production ${ }^{1,2}$
}

\author{
Mario L. Flores-Mangual ${ }^{3}$ and Agenol González-Vélez ${ }^{4}$
}

J. Agric. Univ. P.R. 103(1):27-47 (2019)

\begin{abstract}
Plantains are produced in the mountainous region of Puerto Rico and are grown in highly weathered soils of low fertility and high degradation potential. Alternatives to mitigate soil degradation include the application of chicken manure and the placement of deleafed sigatoka-infected leaves on top of the soil (deleafing). The objective of this study was to determine the effect of chicken manure and deleafing on soil properties and plantain productivity. The experiment was conducted in a Dagüey soil series at the Agricultural Experiment Substation in Corozal, Puerto Rico. The treatments were: 1) 25 ton/ha chicken manure; 2) deleafing; 3) chicken manure + deleafing; and 4) control. Chicken manure was applied before planting, and leaves from deleafing were placed on the soil only in deleafing treatments. The application of chicken manure significantly increased soil aggregate stability, soil available phosphorous and nitrates. Also, plant growth and plantain yield increased with manure applications, and the days to flowering and harvest were reduced. There were no effects neither on soil bulk density, hydraulic conductivity nor on organic matter content. No significant difference in runoff volume was observed, but sediment load in runoff decreased. The deleafed leaves decreased soil penetration resistance.
\end{abstract}

Key words: soils, chicken manure, deleafing, plantain

\section{RESUMEN}

El efecto de la aplicación de gallinaza y el deshoje en las características del suelo y la producción de plátano enano (Musa AAB)

Los plátanos se siembran en la zona central de Puerto Rico en suelos altamente meteorizados con baja fertilidad natural $y$ alto potencial para degradación. Algunas alternativas para mitigar la degradación de suelos incluyen la aplicación de gallinaza, y la colocación sobre el suelo de hojas

${ }^{1}$ Manuscript submitted to Editorial Board on 7 September 2018.

${ }^{2}$ This research was funded with a seed money grant (SM-09) from the Agricultural Experiment Station-UPRM. The authors want to acknowledge José Vigo, Josean Nieves, Lyvette Trabal and Dr. Raúl Machiavelli for their contribution. I would also like to thank the farm workers from the Corozal Agricultural Experiment Substation for their help and support.

${ }^{3}$ Associate Professor, Dept. of Agroenvironmental Sciences, Box 9000, University of Puerto Rico, Mayagüez, PR 00681. *Corresponding author: Mario L. Flores Mangual. Tel.: 787-832-4040, ext. 2526, E-mail address: oxisol@gmail.com

${ }^{4}$ Professor, Dept. of Agroenvironmental Sciences, University of Puerto Rico-Mayagüez, PR 00681. 
cortadas de plátano infectadas con sigatoka negra (deshoje). El objetivo de esta investigación era determinar los efectos de estas prácticas sobre las características del suelo y la producción de plátanos. La investigación se realizó en la Subestación Experimental Agrícola de Corozal, Puerto Rico, en un suelo de la serie Dagüey utilizando la variedad de plátano enano. Los tratamientos fueron: 1) aplicación de 25 ton/ha de gallinaza; 2) aplicación al suelo de hojas de deshoje; 3) aplicación al suelo de gallinaza y hojas de deshoje; y 4) control (no gallinaza, ni hojas en el suelo). La gallinaza se aplicó antes de la siembra, mientras que a todos los tratamientos se les hizo deshoje de hojas infectadas con sigatoka, se aplicaron al suelo las hojas solo en los tratamientos llamados deshoje. La aplicación de gallinaza aumentó la estabilidad de agregados, y las concentraciones de fósforo disponible y nitrato en el suelo. La gallinaza aumentó el crecimiento de la planta y la producción, y redujo el tiempo de florecida y cosecha. No se observaron cambios en la densidad aparente, conductividad hidráulica ni en el contenido de materia orgánica del suelo. El volumen de escorrentía no varió significativamente entre los tratamientos. No obstante, la cobertura de hojas del deshoje redujo significativamente la cantidad de sedimentos arrastrados por la escorrentía. La aplicación de las hojas del deshoje al suelo también redujo significativamente la resistencia a penetración del suelo.

Palabras clave: suelos, gallinaza, deshoje, plátanos

\section{INTRODUCTION}

Plantain and banana are main crops of the mountainous east central region of Puerto Rico (Estación Experimental Agrícola, 1995; Clark, 2009). Many soils in this region are highly weathered with low fertility, requiring intensive fertilization and continuous additions of plant litter, and the storage of soil organic matter for their fertility (Beinroth, 1982; Beinroth et al., 2003; Marín-Spiotta et al., 2007). Farming these soils can significantly reduce litter additions and, thus, soil organic matter content (Marín-Spiotta et al., 2007). Some management strategies that have been studied to increase soil organic matter and nutrient content in Puerto Rico include the use of crop residues, cover crops, chicken manure applications and cattle manure applications (Lugo-López et al., 1981; Muñoz et al., 1990; O'Hallorans et al., 1997; Sotomayor et al., 2008). Poultry manure from poultry farms is produced in large quantities in the central zone of Puerto Rico.

Chicken manure research in Puerto Rico has focused mostly on the benefits to soil fertility, crop yield, and nutrient transport in runoff and leaching water (Lugo-López et al., 1981; Ortega-Achury et al., 2007; Martínez-Rodríguez et al., 2010a; Martínez-Rodríguez et al., 2010b; González-Vélez, 2011; González-Vélez, 2012; Muñoz and Chardón-Alcázar, 2012). González-Vélez (2012) studied the effect of chicken manure (25 ton/ha) on plantain production and soil fertility in an Ultisol in Puerto Rico, finding no significant differences in soil nutrient 
content. However, chicken manure application produced significantly higher yield (33\% greater), larger plant size, stem diameter, and average weight of fruit bunch. There was also a significant increase in leaf nitrogen and calcium content in the manure-applied plots. Muñoz and Chardón-Alcázar (2012) studied the effect of broiler litter on soil exchangeable aluminum of three highly weathered soils of Puerto Rico. They found a significant decrease in exchangeable aluminum in Consumo and Corozal soils, both Ultisols. They also observed an increase in available phosphorus in Coto soil (Oxisol), but not for the Consumo and Corozal.

An environmental concern of applying manure to fertilized soils is risk of increasing the available phosphorus to levels that can cause soil contamination and water pollution (Ortega-Achury et al., 2007). Phosphorus losses in runoff water can be significant when the manure is not incorporated into the soil after surface application (SotomayorRamírez et al., 2006; Ortega-Achury et al., 2007). Martínez-Rodríguez et al. (2010a) explored the use of alum $\left[\mathrm{Al}_{2}\left(\mathrm{SO}_{4}\right)_{3} \cdot 14 \mathrm{H}_{2} \mathrm{O}\right]$ as an amendment to reduce phosphorus from manure. They found that in the control soils (no alum) the amount of available P increased three and eight times the established agronomic criteria $(35 \mathrm{mg} / \mathrm{kg})$ for applications of 6 ton/ha and 20 ton/ha broiler litter, respectively. However, the application of alum in combination with the chicken manure significantly reduced the total $\mathrm{P}$ and the dissolved $\mathrm{P}$ in the soil, resulting in a reduction of $\mathrm{P}$ in runoff water. Other strategies for reducing $\mathrm{P}$ in runoff water of manure-applied soils include the use of cover crops and grass filter strips with different levels of success (Sotomayor-Ramírez et al., 2008; Martínez-Rodríguez et al., 2010b).

Organic amendments, including crop residues and animal manure, have been tested as a management practice to restore degraded soils and improve soil quality (O'Hallarans et al., 1993; Sotomayor-Ramírez et al., 2010; González-Vélez, 2011). Soil erosion is a major cause of soil degradation that can affect soil water infiltration, aggregate stability, soil bulk density, and soil penetrability. All these properties affect plant growth and yield; for example, soil penetrability and bulk density affect root development and growth (Rosales et al., 2008). Soil amendments can improve and promote aggregate formation and stability, water infiltration, and soil water retention (Lowery et al., 1998; Ferraras et al., 2006). In addition, plant material or other organic materials on the soil surface can serve as protection against soil water erosion including protection from rainfall and runoff (Lugo-López et al., 1981; Hillel, 2004).

Another source of organic material and possible soil amendment in plantain and banana plantations are leaves from the practice of de- 
leafing of sigatoka-infected leaves. Sigatoka is a disease caused by the fungus Mycosphaerella fijiensis and its severity can be reduced by cutting off infected leaves and placing them on top of the soil (Marín et al., 2003; González-Vélez, 2012; González-Vélez, 2014). This, in turn, adds organic matter to the soil and protects it against erosion. Chicken manure additions and leaves from deleafing could improve soil properties and mitigate soil degradation. The present study was conducted to assess their effect on soil properties and plantain yield.

\section{MATERIALS AND METHODS}

\section{Site Description}

The research site was located at the Corozal Agricultural Experiment Substation of the University of Puerto Rico. The soil series was Dagüey (Very-fine, kaolinitic, isohyperthermic Inceptic Hapludox) formed from weathered volcanic rock, set on gentle to steep slopes (2 to 40 percent) of volcanic uplands (Soil Survey Staff, 2018). The slope of the experimental site was approximately $15 \%$. The soil chemical characterization of the experimental plots before treatment applications showed a moderately acidic $\mathrm{pH}$ (5.56), with low content of soil organic matter (1.35\%), low bulk density $\left(0.95 \mathrm{~g} / \mathrm{cm}^{3}\right)$, and concentrations of $\mathrm{Ca}, \mathrm{K}, \mathrm{Mg}$ and $\mathrm{Al}$ of $9.56,0.53,0.93$, and $1.29 \mathrm{cmol}_{\mathrm{c}} \mathrm{kg}$, respectively. For more than five years previously the site was used for the production of taro (Xanthosoma spp.) and forage.

\section{Experimental Design}

A complete randomized block design with four repetitions was used in the experiment to test the effect of treatments on soil characteristics and Dwarf plantain (Musa AAB) production. The treatments were: 1) 25 ton/ha chicken manure incorporated to the soil (chicken manure); 2) deleafing and placement of the leaves on top of the soil (deleafing); 3) chicken manure and deleafing; and 4) control. All treatments included deleafing of sigatoka-infected leaves, but in the control and chicken manure treatment the leaves were removed from the plots.

Plot size was $12.2 \mathrm{~m}$ by $6.1 \mathrm{~m}$; plots were positioned along the slope. Each plot included 20 plantain plants (1,088 plants per acre) as recommended by the Agricultural Experiment Station (AES) of the University of Puerto Rico (Estación Experimental Agrícola, 1995). Chicken manure was applied before planting and incorporated into the soil using a rototiller at the rate of $25 \mathrm{ton} / \mathrm{ha}$ (González-Vélez, 2012). Herbicides and pesticides were applied following the recommendations of AES and the product label instructions (Estación Experimental Agrícola, 
1995). Nematicide (Etoprop $10 \mathrm{G}, 60 \mathrm{~g} /$ plant) was applied to the hole at planting. Nematodes were controlled with Oxamyl (10 ml/plant, $24 \%$ of active ingredient) six and 12 months after planting.

\section{Soil Preparation}

The soil was tilled two times with moldboard tillage (15- to $18-\mathrm{cm}$ soil depth), afterwards raked and rototilled to a depth of 15 to $20 \mathrm{~cm}$. Chicken manure was applied to the soil surface and incorporated into the soil between raking and rototilling. The chicken manure contained approximately $92 \%$ of dry matter, had a $\mathrm{pH}$ of 8.25 , an electrical conductivity (EC) of $806 \mathrm{dS} / \mathrm{m}$ and concentrations of phosphorous (Total $\mathrm{P}$ ), $\mathrm{Ca}$ and $\mathrm{Na}$ of 3,$026 ; 4,134$ and $7,287 \mathrm{mg} / \mathrm{kg}$, respectively (Table 1). Inorganic 10-2-25-3 Mg fertilizer was added superficially at rate of 0.23 kg per plant at two months after planting. Three additional applications were performed at five months $(0.34 \mathrm{~kg} /$ plant $)$, eight months $(0.45$ $\mathrm{kg} / \mathrm{plant})$, and $10 \mathrm{months}(0.23 \mathrm{~kg} / \mathrm{plant})$ after planting.

\section{Soil sampling and plantain yield}

Soil surface samples ( 0 to $15 \mathrm{~cm}$ ) were collected before treatment applications and at harvesting. The growing cycle up to harvesting lasted 16 months. The following soil characteristics were measured: soil aggregate stability (Nimmo and Perkins, 2002) and texture (Gee and Or, 2002). Chemical analyses were performed in the Central Analytical Laboratory of AES at Río Piedras, Puerto Rico. Exchangeable basic cations $\mathrm{Ca}^{+2}, \mathrm{~K}^{+}, \mathrm{Na}^{+}$and $\mathrm{Mg}^{+2}$ were determined by the ammonium acetate method (Wright and Stuczynski, 1996), and available $\mathrm{P}$ by the Bray I colorimetric method and determined using a UV Spectrophotometer (Bray and Kurtz, 1945). The $\mathrm{N}_{-} \mathrm{NH}_{4}{ }^{+}$and $\mathrm{N}_{-} \mathrm{NO}_{3}{ }^{-}$were determined in $\mathrm{KCl}$ soil extract using flow injection analysis (QuickChem ${ }^{\circledR}$ Method 12-107-06-1-A for $\mathrm{NH}_{4}^{+}$and QuickChem ${ }^{\circledR}$ Method 12107-04-1-B for $\mathrm{NO}_{3}^{-}$; Wendt, 1995). Organic matter was determined by the Walkley-Black method (Nelson and Sommers, 1996), soil pH was measured in a 2:1 water to soil ratio (Thomas, 1996), and effective

TABLE 1.-Chicken manure chemical properties including $p H$, electrical conductivity (EC), organic matter (OM), effective cation exchange capacity (ECEC), total Kjeldahl nitrogen, phosphorous, calcium, magnesium, sodium, and aluminum.

\begin{tabular}{|c|c|c|c|c|c|c|c|c|c|}
\hline \multirow[b]{2}{*}{$\mathrm{pH}$} & \multirow{2}{*}{$\begin{array}{l}\text { E.C. } \\
\text { dS } / m\end{array}$} & \multirow{2}{*}{$\begin{array}{c}\mathrm{OM} \\
\%\end{array}$} & \multirow{2}{*}{$\begin{array}{c}\text { ECEC } \\
\mathrm{cmol}_{c} \mathrm{~kg}\end{array}$} & \multirow{2}{*}{$\begin{array}{c}\text { Total N } \\
\%\end{array}$} & $\mathrm{P}_{-} \mathrm{PO}_{4}$ & $\mathrm{Ca}$ & $\mathrm{Mg}$ & $\mathrm{Na}$ & $\mathrm{Al}^{+}$ \\
\hline & & & & & \multicolumn{5}{|c|}{ 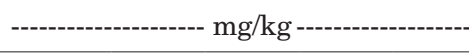 } \\
\hline 8.25 & 806 & 39.0 & 126 & 3.62 & 3,026 & 4,134 & 729 & 7,287 & ND \\
\hline
\end{tabular}

$\dagger \mathrm{ND}$ refers to non-detected. 
cation exchange capacity (ECEC) by the sum of cations (Sumner and Miller, 1996). Soil electrical conductivity was measured in a 2:1 water to soil ratio and exchangeable $\mathrm{Al}$ was extracted with $1 \mathrm{~N} \mathrm{KCl}$ (Bertsch and Bloom, 1996). Soil penetration resistance was determined using a soil cone penetrometer (CP40II Cone Penetrometer, Rimik Corp., Queensland, Australia) ${ }^{5}$ from 0 - to $60-\mathrm{cm}$ depth (Lowery and Morrison, 2002). Soil bulk density was measured from undisturbed soil samples collected with a core $(7 \mathrm{~cm}$ length and $7 \mathrm{~cm}$ diameter) sampler (0- to 7-cm depth; Grossman and Reinsch, 2002). Constant head soil water infiltration was determined by Guelph methodology, by ponding the soil with a constant head of water using a bronze cylinder of $10.2 \mathrm{~cm}$ diameter inserted in the soil and measuring periodically the amount of water supplied into the core by the instrument (Reynolds and Elrick, 2002). Soil penetration resistance, soil bulk density and water infiltration were determined at two months and 16 months (end of harvest) after planting.

Soil erosion data was collected during March 2014 from subplots in the middle of each plot. Sediment collection areas $(1.2 \mathrm{~m} \mathrm{x} 1.8 \mathrm{~m})$ were delimited using $25-\mathrm{cm}$ high garden liners. The collection areas were placed in the direction of the soil slope. Soil erosion rates were determined for selected rain events using erosion collectors that fractionalized the runoff output to one tenth of the total runoff. Water runoff was funneled at the "downhill" portion of each erosion subplot where the runoff fractionators were installed. The volume of water runoff was measured using a calibrated cylinder. The water with sediment from each rain collector was dried to measure the amount of sediment collected using a convective oven ( 48 to $72 \mathrm{~h}$ at $105^{\circ} \mathrm{C}$ ). Rainfall data was collected every 30 minutes using a tipping bucket rain gauge (Rain Collector, Davis Instruments Co., California, USA) connected to a data logger (HOBO Pendant $^{\circledR}$ Event Data Logger, Onset Computer Co., Massachusetts, USA). Plantain bunch weight, number of fruits per bunch, and average fruit weight were recorded. The plant parameters measured were: 1) number of fallen plants, 2) pseudostem diameter at 1-meter height, 3) plant height, 4) number of harvested plants, and 5) days to flowering.

Statistical analyses for all data, except soil penetration resistance data, were performed using analysis of variance (ANOVA) (JMP 8, SAS Institute, North Carolina, USA). The effects in the ANOVA were treatment (manure, and no-manure application), ground cover (cut sigatoka

${ }^{5}$ Company or trade names in this publication are used only to provide specific information. Mention of a company or trade name does not constitute an endorsement by the Agricultural Experiment Station of the University of Puerto Rico, nor is this mention a statement of preference over other equipment or materials. 
leaves placed on the ground, and no-leaves placed on the ground), and the interaction between treatment and ground cover. There were four repetitions for each treatment. For soil penetration resistance, data was analyzed using repeated measures ANOVA with a covariate structure that best fit the data set (Littell et al., 1998; SAS Institute, 2013). The soil penetration resistance ANOVA included also the effect of soil depth. Means comparison analyses were performed for significant effects using an alpha of 0.05 .

\section{RESULTS AND DISCUSSION}

\section{Soil chemical characteristics}

There were no significant differences among treatments for $\mathrm{pH}, \mathrm{OM}$, $\mathrm{Ca}^{+2}, \mathrm{Al}^{+3}$, and ECEC (Tables 2 and 3). However, chicken manure significantly increased the amount of $\mathrm{N}_{-} \mathrm{NO}_{3}^{-}$, available $\mathrm{P}, \mathrm{K}^{+}$, and $\mathrm{Mg}^{+2}$ compared to plots with no-chicken manure application (Table 2 and Figure 1). Available $P(121 \mathrm{mg} / \mathrm{kg})$ in manure-applied soils was at a high level for soils in Puerto Rico (20 mg/kg of Bray 1 available P is considered high) as established by Sotomayor-Ramírez and Martínez (2006) (Figure 1). Phosphate movement into runoff water, one of the major concerns on manure-applied soils, is dependent on when the rainfall occurs after manure application (Sotomayor-Ramírez et al., 2006; Ortega et al., 2007). Ortega et al. (2007) found in a Mollisol (Soller series, 12\% slope) and two Ultisols (Consumo and Naranjito series, 25-35\% slope) with grass cover that dissolved $\mathrm{P}$ concentration in runoff was high when rain events occurred five days or less after applying manure (dairy and poultry manure) to the soil. Similarly, Sotomayor-Ramírez et al. (2006) found on a Puerto Rico farm with naturalized pastures and Humatas soil series (Typic Haplohumults) that phosphorus losses in runoff were higher if rain events occurred within 10 days after fertilization or organic amendment application. High amounts of $\mathrm{P}$ in runoff water could be related to the amount of $\mathrm{P}$ mineralization after applying the manure to the soil. De Souza et al. (2011) found in an Oxisol in Brazil that P mineralization of different kinds of chicken manure occurred during the first 15 days after applying the manure to the soil.

Manure application significantly increased EC to $0.42 \mathrm{dS} / \mathrm{m}$, while EC without manure application was $0.22 \mathrm{dS} / \mathrm{m}$ (Table 2). This was expected because there was a high EC in the manure (Table 1). It has been found in a manure incubation experiment using an Ultisol of Hawaii, among other soils and amendments, that applications of chicken manure of 10 ton/ha increased the EC from 0.08 to $0.92 \mathrm{dS} / \mathrm{m}$ after 42 days of incubation (Ortiz-Escobar and Hue, 2008). However, at 56 days 


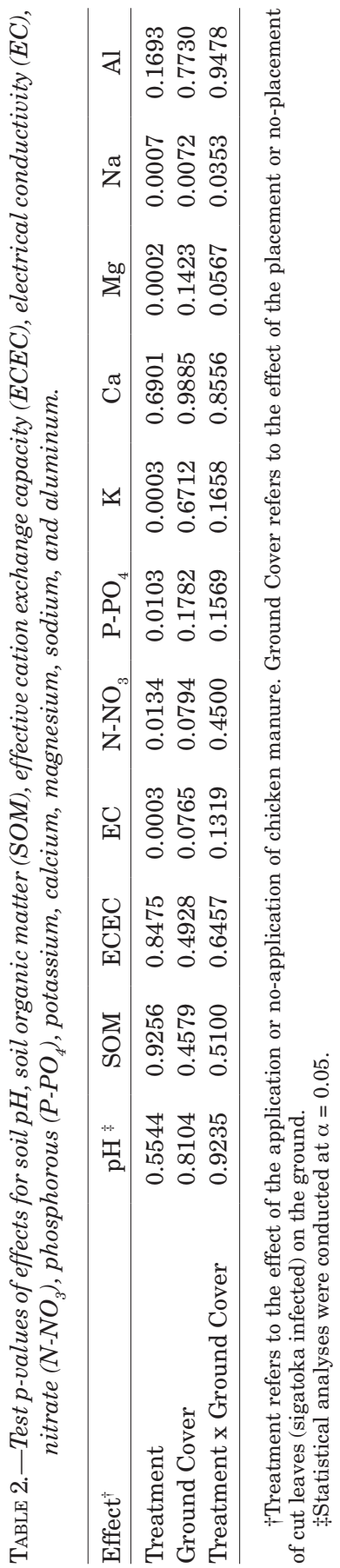


TABLE 3.-Soil chemical properties at the end of plantain harvest ${ }^{*}$.

\begin{tabular}{|c|c|c|c|c|c|c|}
\hline & \multirow[b]{2}{*}{$\mathrm{pH}$} & \multirow{2}{*}{$\begin{array}{c}\mathrm{SOM}^{\ddagger} \\
\end{array}$} & $\mathrm{Ca}^{+2}$ & $\mathrm{Na}^{+}$ & $\mathrm{Al}^{+3}$ & ECEC \\
\hline & & & \multicolumn{4}{|c|}{------------ $\mathrm{cmol}_{\mathrm{c}} \mathrm{kg}$----------- } \\
\hline Chicken Manure + Deleafing & 5.40 & 2.19 & 9.12 & $0.12 \mathrm{~b}$ & 0.62 & 12.35 \\
\hline Chicken Manure & 5.32 & 3.42 & 8.92 & $0.28 \mathrm{a}$ & 0.77 & 13.10 \\
\hline Deleafing & 5.53 & 2.69 & 9.35 & $0.06 \mathrm{~b}$ & 1.52 & 12.53 \\
\hline Control & 5.50 & 2.76 & 9.52 & $0.09 \mathrm{~b}$ & 1.75 & 12.75 \\
\hline
\end{tabular}

$†$ Pair-wise comparisons were done using Tukey LS means. Means with different letters within columns are significantly different $(\alpha=0.05)$.

†SOM = Soil organic matter.

of incubation the EC decreased to $0.46 \mathrm{dS} / \mathrm{m}$. A possible explanation for this behavior is that mineralization increased the EC but later the mineralized cations and anions were adsorbed into the soil, decreasing the EC (Ortiz-Escobar and Hue, 2008).

Although chicken manure increased the EC, all values were below the soil salinity levels (Brady and Weil, 2010). Exchangeable $\mathrm{Na}$ also significantly increased with chicken manure application, especially when only chicken manure was applied (Table 3). However, the exchangeable $\mathrm{Na}$ in the chicken manure treatments were below the levels that could affect soil structure and plant growth (Figure 2) (Bonnet, 1960; Brady and Weil, 2010). In the highly weathered soils of Puerto Rico that are naturally low in salts and exchangeable sodium, high values of EC and exchangeable $\mathrm{Na}^{+}$should not be a problem. Intense rainfall in the area will prevent salinity problems. However, intensive and

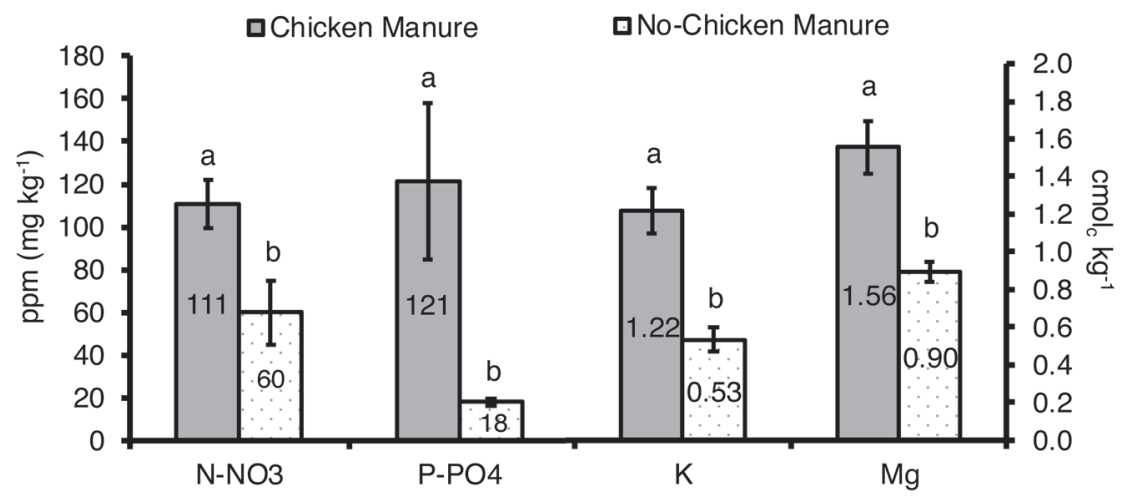

FIGURE 1. Soil nutrient means comparison for the effects of soil applied chicken manure vs. no-manure application. The $\mathrm{N}-\mathrm{NO}_{3}$ and $\mathrm{P}-\mathrm{PO}_{4}$ are expressed in $\mathrm{mg} / \mathrm{kg}$, while the $\mathrm{K}$ and $\mathrm{Mg}$ are in $\mathrm{cmol}_{\mathrm{c}} / \mathrm{kg}$. Pair-wise comparisons were done using Tukey LS means. Means with different letters are significantly different $(\alpha=0.05)$. 


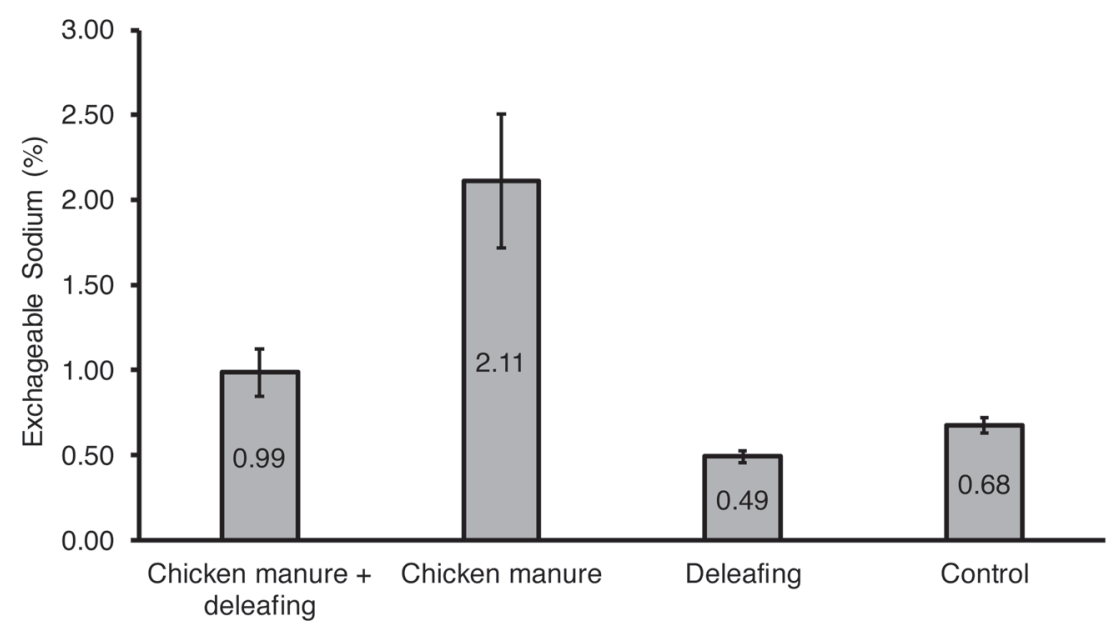

Figure 2. Exchangeable sodium percentage means comparison.

long-term manure application could cause salinity problems in soils with low drainage and semiarid conditions, often found on the southern coast of Puerto Rico (Bonnet, 1960; Pérez-Escolar and Ortiz-Vélez, 1979).

Soil organic matter (SOM) was not significantly increased by chicken manure or deleafing, although the chicken manure treatment created the greatest value of SOM (3.42\%) (Tables 2 and 3). Nevertheless, all treatments increased the amount of SOM compared to the amount before planting and treatment applications from $1.35 \%$ to between 2.19 and $3.42 \%$ (Table 3). Likewise, González-Vélez (2011) did not find a significant increase in SOM with an application of manure $(25 \mathrm{t} / \mathrm{ha})$ to Corozal soil (Typic Haplohumults) in Puerto Rico. Other studies related to organic amendments and chicken manure applications have reported increases in SOM (Scotti et al., 2015; Pagán-Roig et al., 2016).

Soil physical characteristics

Aggregate stability (AS) significantly increased with chicken manure application $(8.6 \% \mathrm{AS}$ with chicken manure and $5.8 \% \mathrm{AS}$ without chicken manure) (Table 4). Although there was a significant increase in AS in chicken manure applied soils, there were no significant differences in the amount of SOM (Table 2). Other studies have found a correlation between the amount of SOM and AS. Ferreras et al. (2006) found increases in AS, organic carbon (OC) and soil respiration in a Vertic Argiudoll in Argentina when chicken manure was applied. In addition, they found a strong correlation between OC and AS. Snyder et al. (1993) also found a positive correlation between the amount of OC 
TABLE 4.-Test p-values of effects for soil hydraulic conductivity (Ks), bulk density (Db), soil aggregate stability (AS), sand, silt, and clay.

\begin{tabular}{lcccccc}
\hline Effect $^{\dagger}$ & $\mathrm{Ks}^{\ddagger}$ & $\mathrm{Db}$ & $\mathrm{AS}$ & Sand & Silt & Clay \\
\hline Treatment & 0.3072 & 0.8510 & 0.0313 & 0.3390 & 0.1201 & 0.8822 \\
Ground Cover & 0.2240 & 0.8294 & 0.3835 & 0.5821 & 0.6568 & 0.5542 \\
Treatment x Ground Cover & 0.6945 & 0.4291 & 0.4163 & 0.9029 & 0.2847 & 0.6176 \\
\hline
\end{tabular}

$\dagger$ Treatment refers to the effect of the application or no-application of chicken manure. Ground Cover refers to the effect of the placement or no-placement of cut leaves (sigatoka infected) on the ground.

$\ddagger$ Statistical analyses were conducted at $\alpha=0.05$.

and AS in highly weathered soils in Puerto Rico, including the Dagüey soil series. Therefore, since there was no significant difference in OM, other mechanisms or different types of organic materials and cementing materials in the chicken manure may be causing an increase in AS.

Pagán-Roig et al. (2016) found that the combined soil application of coffee compost, green manure and mycorrhiza significantly increased AS, OC, and soil humic acid. Humic acid can form clay-humic complexes by attaching to divalent cations absorbed in clays (Piccolo et al., 1997). This process joins different clays, positioning chelating acidic groups of the humic acid to the interior of the aggregate, while positioning the more aromatic hydrophobic and aliphatic groups to the exterior of the aggregate, making the aggregate interior less wettable and more resistant to air slaking (Piccolo et al., 1997).

The greater AS could also be related to greater soil biological activity promoted by chicken manure. Microbial activity can be promoted by additions of SOM, and, in turn, this promotes the particle binding mechanisms of soil microbes (Six et al., 2004; Consentino et al., 2006). The soil bacteria and fungi can produce polysaccharides that help bind the soil particles (Six et al., 2004). This binding promoted by microbial activity increases the aggregate internal cohesion (Consentino et al., 2006). In addition, fungi can entangle soil aggregates by the production of hyphae (Six et al., 2004). Moreover, the amount of fungi biomass has a stronger correlation with soil AS than bacterial biomass, most likely due to fungi promoting more mechanisms of physical entanglement of aggregates, more production of hydrophobic substances and the production of polysaccharides (Consentino et al., 2006). There were no significant differences for soil hydraulic conductivity $\left(\mathrm{K}_{\mathrm{s}}\right)$, bulk density and particle size in all treatments (Table 4). However, on the soil surface, all treatments had low soil bulk density $\left(1.15 \mathrm{~g} / \mathrm{cm}^{3}\right)$, thus indicating high porosity and sufficient pore space for oxygen movement at the surface. The mean value of $\mathrm{K}_{\mathrm{s}}$ for all treatments was $6.6 \mathrm{~cm} / \mathrm{h}$, and the percentage of sand, silt and clay were $27.1,15.0$ and 57.9, respectively. 
The soil cone index (soil penetration resistance) increased with depth, but it was similar in all treatments at two months after planting (Figure 3). However, the cone index at the end of harvest showed significant differences for the effects of soil depth, treatment (manure application), ground cover and the interaction of treatment and ground cover (Figure 4). The means comparisons for the combined effects of treatment and ground cover showed that control (no manure or ground cover from deleafing) had significantly more penetration resistance than the other treatments (Table 5). Meanwhile the manure treatment had greater penetration resistance than the deleafing treatment (Table 5). The greater resistance to penetration at harvest should be expected because the soil settled through the growing season to a more compacted volume (Figure 4). Also, after harvest the increase in cone index with soil depth

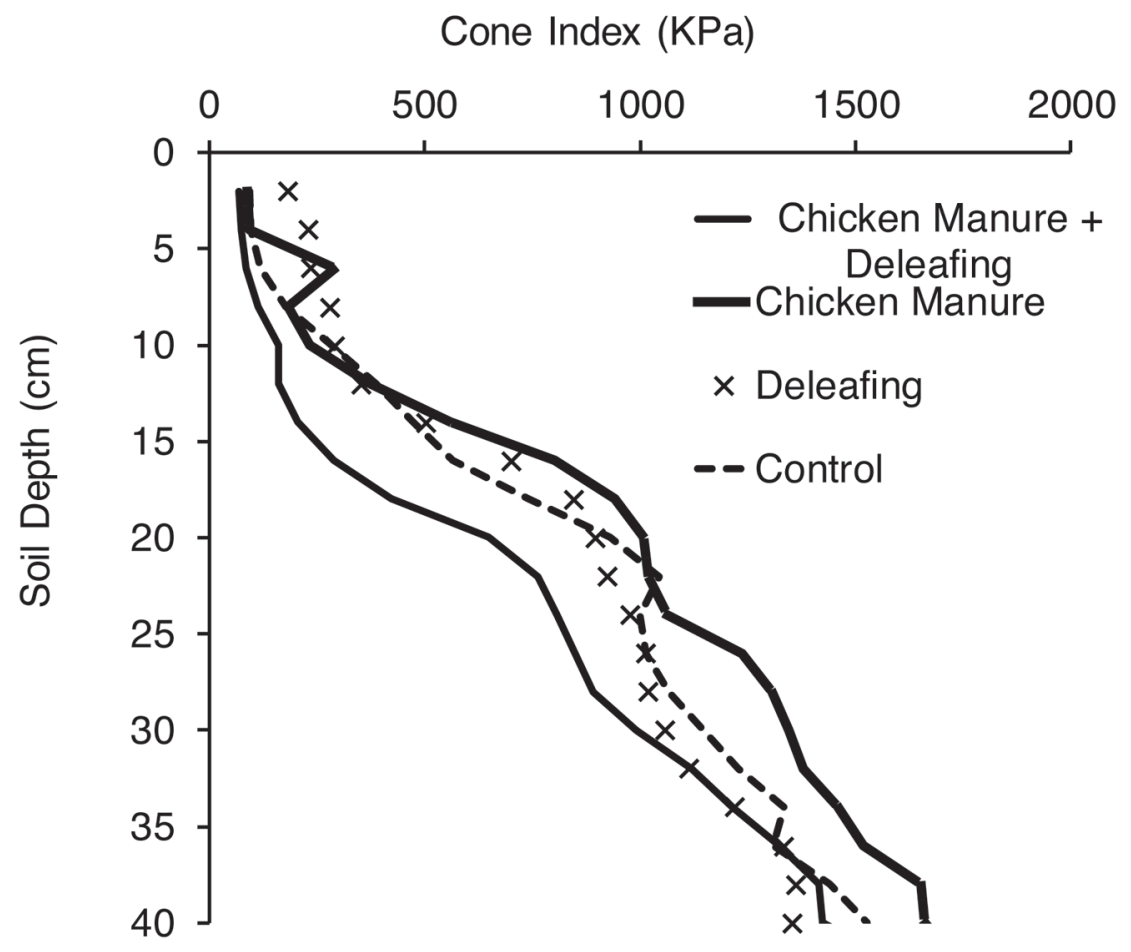

FiguRE 3. Soil penetration resistance two months after planting. Whole model for cone index: Treatment $\mathrm{F}_{1},{ }_{276}=0.10, \mathrm{P}$ value $=0.7475 ;$ Ground Cover $\mathrm{F}_{1},{ }_{276}=0.03, \mathrm{P}$ value 0.8706; Treatment by Ground Cover $\mathrm{F}_{1},{ }_{276}=0.08, \mathrm{P}$ value 0.7769 ; Depth $\mathrm{F}_{39},{ }_{276}=0.50$, $\mathrm{P}$ value $=0.9947$; Treatment by Depth $\mathrm{F}_{16},{ }_{276}=0.02, \mathrm{P}$ value $=1.0000 ;$ Ground Cover by Depth $\mathrm{F}_{28},{ }_{276}=0.02, \mathrm{P}$ value $=1.0000$; Treatment by Ground Cover by Depth $\mathrm{F}_{5},{ }_{276}=$ $0.04, \mathrm{P}$ value $=0.9993$. 


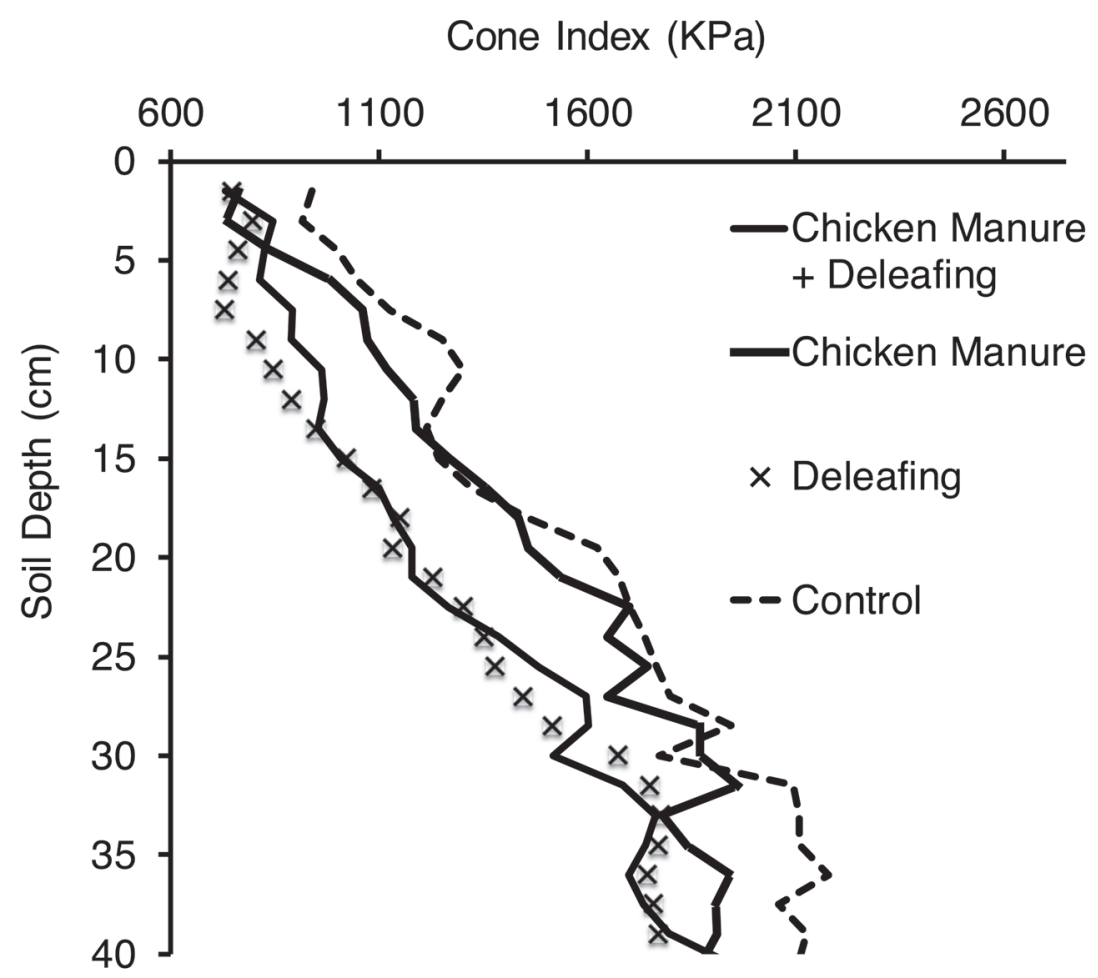

Figure 4. Soil penetration resistance at the end of harvest. Whole model for cone index: Treatment $\mathrm{F}_{1},{ }_{480}=9.50, \mathrm{P}$ value $=0.0022 ;$ Ground Cover $\mathrm{F}_{1},{ }_{480}=59.18, \mathrm{P}$ value $<0.0001$; Treatment by Ground Cover $\mathrm{F}_{1},{ }_{480}=18.17, \mathrm{P}$ value $<0.0001$; Depth $\mathrm{F}_{39},{ }_{480}=$ 22.55, $\mathrm{P}$ value $=<0.0001$; Treatment by Depth $\mathrm{F}_{39}{ }_{480}=0.34, \mathrm{P}$ value $=0.9999$; Ground Cover by Depth $\mathrm{F}_{39}{ }_{480}=0.82, \mathrm{P}$ value $=0.7743$; Treatment by Ground Cover by Depth $\mathrm{F}_{39},{ }_{480}=0.55, \mathrm{P}$ value $=0.9892$.

was greater in the manure and control treatments than in the deleafing and manure + deleafing treatments (Figure 4). Lugo-Mercado et al. (1978) found in a Corozal soil series that tanier (Xanthosoma spp.) production was significantly reduced at levels of soil penetration resistance of $25 \mathrm{~kg} / \mathrm{cm}^{2}(2,452 \mathrm{kPa})$ or higher. Although this degree of penetration resistance was not reached in any of the treatments (Figures 3 and 4), the recommended soil penetration resistance for banana and plantains should not exceed $1,500 \mathrm{kPa}$ in the first $80 \mathrm{~cm}$ of root zone (Robinson and Galán-Saúco, 2010). This value was exceeded at the beginning of the experiment at depths greater than $30 \mathrm{~cm}$ for all treatments; however, after harvest, in the manure and control treatments it was reached at $20-\mathrm{cm}$ deep, and in the deleafing and manure + deleafing treatments at 30$\mathrm{cm}$ deep (Figure 4). Soil mechanical impedance can significantly restrict 
TABLE 5. - Soil penetration resistance at the end of plantain harvest. ${ }^{\dagger}$

\begin{tabular}{lc}
\hline & Cone Index \\
\cline { 2 - 2 } & $\mathrm{kPa}$ \\
\hline Chicken Manure + Deleafing & $1,474 \mathrm{bc}$ \\
Chicken Manure & $1,565 \mathrm{~b}$ \\
Deleafing & $1,442 \mathrm{c}$ \\
Control & $1,760 \mathrm{a}$ \\
\hline
\end{tabular}

$\dagger$ Pair-wise comparisons were done using Tukey LS means. Means with different lowercase letters within columns are significantly different $(\alpha=0.05)$.

banana root growth, especially by reducing the soil volume explored by roots (Draye, 2002). Moreover, this promotes the growth of thicker roots, that are less efficient in absorbing soil nutrients (Draye, 2002). In addition, higher values of soil penetration resistance can be correlated with low oxygen availability in the root zone and lower plant production (Draye, 2002; Robinson and Galán-Sauco, 2010).

\section{Soil erosion and water runoff}

For the runoff and soil erosion analyses, several rainfall events that produced runoff were selected (Table 6). Rain events during the growing season ranged from $3.8 \mathrm{~mm}$ to $47 \mathrm{~mm}$ of cumulative amount of rainfall (Table 6). There were no significant differences in runoff during the rain events (Table 7). The amount of runoff was similar for all treatments in each rain event (Figure 5). The results on runoff volume during rain events among treatments coincide with the lack of significant differences in saturated hydraulic conductivity (Table 4). On the other hand, sediment loads were significantly different for the effect of

TABLE 6.-Rainfall amounts and intensities for selected rain events.

\begin{tabular}{lcc}
\hline & Rainfall Amount & Rainfall Intensity \\
\cline { 2 - 3 } Date & $\mathrm{mm}$ & $\mathrm{mm} / \mathrm{h}$ \\
\hline 26 Nov 2014 & 10.2 & 0.4 \\
1 Dic 2014 & 5.2 & 1.0 \\
5 Dic 2014 & 21.8 & 2.9 \\
20 Jan 2015 & & \\
2 Feb 2015 & & \\
17 Feb 2015 & 8.6 & 1.4 \\
23 Feb 2015 & 3.8 & 1.0 \\
1 Jun 2015 & 47 & 1.6 \\
4 Jun 2015 & 21.8 & 14.5 \\
\hline
\end{tabular}

$\dagger$ The precipitation of rain events of 20 January and 2 February 2015 could not be recorded. 
TABLE 7.-Test p-values of effects for runoff and sediment load during selected rain events.

\begin{tabular}{lcc}
\hline Effect ${ }^{\dagger}$ & Runoff ${ }^{\ddagger}$ & Sediment load \\
Treatment & 0.4666 & 0.4914 \\
Ground Cover & 0.1952 & 0.0311 \\
Treatment x Ground Cover & 0.5031 & 0.0622 \\
Rain Event & 0.0508 & 0.0827 \\
Treatment x Rain Event & 0.7601 & 0.9941 \\
Ground Cover x Rain Event & 0.0904 & 0.7117 \\
Treatment x Ground Cover x Rain Event & 0.6918 & 0.5947 \\
\hline
\end{tabular}

$\dagger$ Treatment refers to the effect of the application or no-application of chicken manure. Ground Cover refers to the effect of the placement or no-placement of cut leaves (sigatoka infected) on the ground. Rain event refers to the effect of the rain events on runoff and sediment load.

$\ddagger$ Statistical analyses were conducted at $\alpha=0.05$.

ground cover (Table 7). Sediment load in the subplots were more than double where no leaves were placed on the ground $\left(12.0 \mathrm{~g} / \mathrm{m}^{2}\right) \mathrm{com}$ pared to sigatoka cut leaves placed over the ground as cover $\left(5.6 \mathrm{~g} / \mathrm{m}^{2}\right)$. This difference in sediment load due to the effect of ground cover was more obvious for the rain events on 23 February, 1 June and 4 June 2015 (Figure 6). The magnitude of the differences in sediment load can be observed more clearly by transforming the amount of sediment load in the subplots to $\mathrm{kg} / \mathrm{ha}$ for these three rain events (Table 8). During the rain event of 4 June 2015, in particular, no-ground cover treatments (manure, and control) averaged 1,093 kg/ha while the ground cover treatments (deleafing, and manure+deleafing) averaged $60 \mathrm{~kg} / \mathrm{ha}$ with a rainfall intensity of $14.5 \mathrm{~mm} / \mathrm{h}$ (Tables 6 and 8). The leaves from

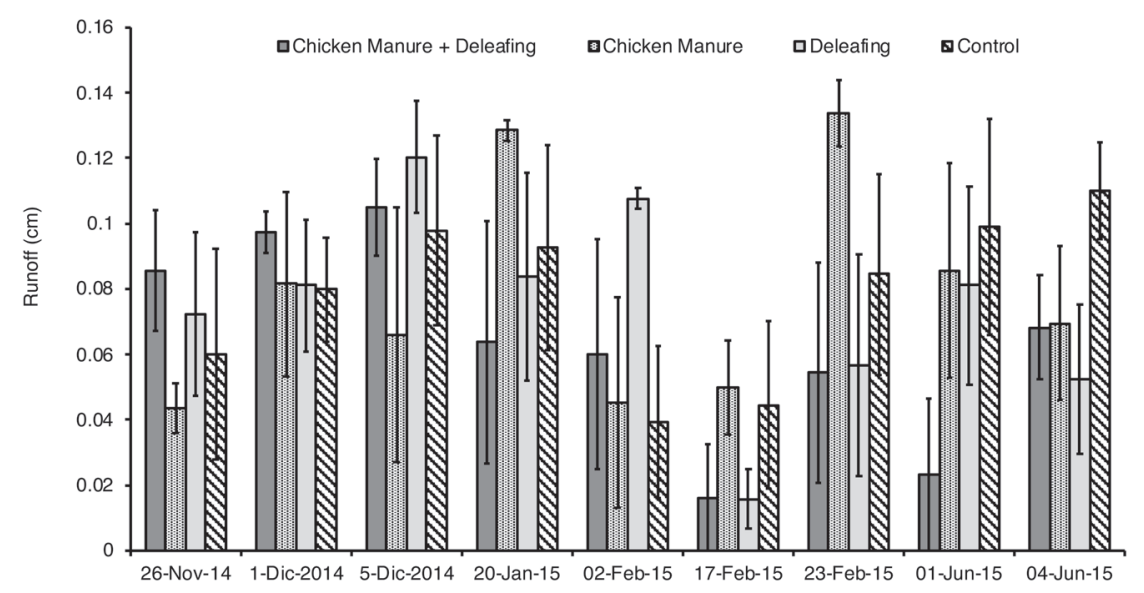

FiguRe 5. Runoff in $1.2 \mathrm{~m}$ x $1.8 \mathrm{~m}$ subplots during selected rain events. 


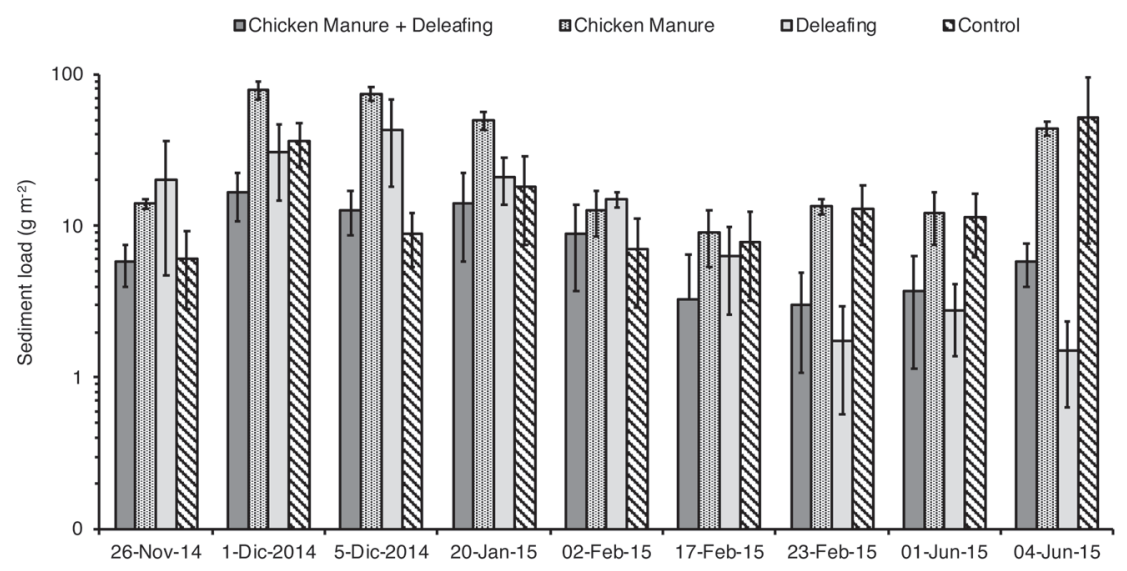

FiguRE 6. Sediment load in runoff in $1.2 \mathrm{~m}$ x $1.8 \mathrm{~m}$ subplots.

deleafing placed over the soil surface functioned as a mulch to control erosion. On a banana plantation with a highly permeable Andosol in Guadeloupe, Cattan et al. (2006) found that waste banana material in the soil surface from previous harvests significantly reduced the amount of runoff.

\section{Plant growth and crop yield}

Plant height and diameter at breast height (DBH) differed significantly for the effects of manure treatment, ground cover and the interaction between manure treatment and ground cover (Table 9). Days to flowering and weight of plantain bunch were significantly different for the effects of manure treatment and ground cover, but not because of the interaction of effects (Table 9). Days to harvest and hands per bunch differed significantly only for manure treatment (Table 10).

TABLE 8.-Sediment load during means comparison during selected rain events.

\begin{tabular}{|c|c|c|}
\hline Rain event ${ }^{\dagger}$ & Ground Cover & No-Ground Cover \\
\hline \multicolumn{3}{|c|}{ - } \\
\hline 23 Feb 2015 & 69 & 161 \\
\hline 1 Jun 2015 & 89 & 215 \\
\hline 4 Jun 2015 & 60 & 1,093 \\
\hline
\end{tabular}

$\dagger$ Rain event refers to the date of the selected rain event. Ground cover refers to cut sigatoka leaves placed on the ground. No- ground cover refers to extraction and no placement on the ground of cut sigatoka leaves

$\ddagger$ Statistical analyses were conducted at $\alpha=0.05$. 
J. Agric. Univ. P.R. vol. 103, No. 1, 2019

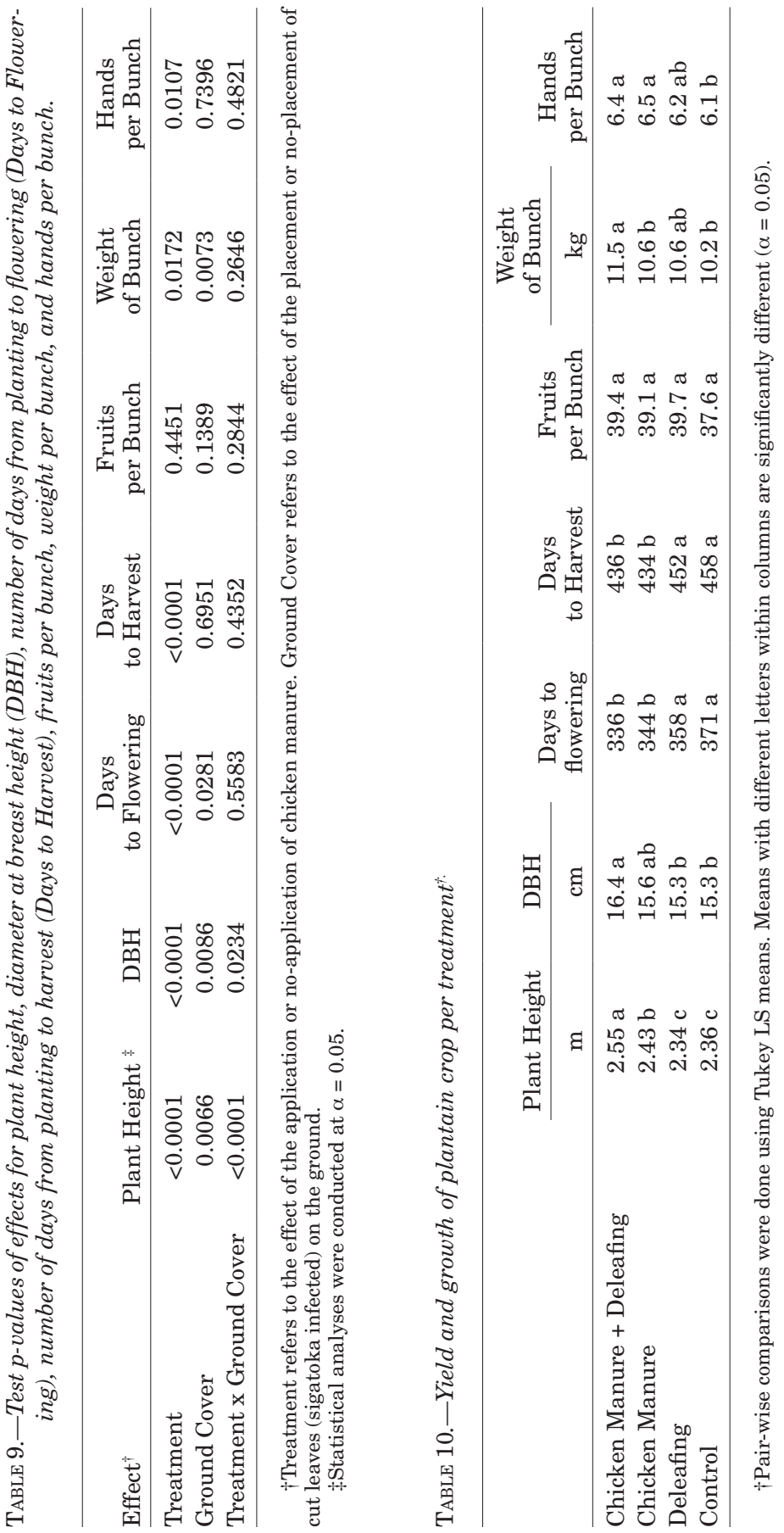


There were no significant differences in the amount of fruits per bunch (Table 10). Plant height was significantly greater in the treatment of chicken manure + deleafing, followed by chicken manure, than the treatment without manure (Table 10). The DBH of plants was also greater in chicken manure + deleafing treatment than deleafing and control treatments. The DBH in chicken manure was not significantly different compared to the other treatments. Both days to flowering and days to harvest were significantly fewer in the treatments with chicken manure compared to treatments without chicken manure (Table 10). The bunch weight was greater in the chicken manure + deleafing than chicken manure and control treatments (Table 10). Hands per bunch were significantly greater in both chicken manure treatments compared to control. González-Vélez (2012) in a Corozal soil series found that chicken manure ( 25 ton/ha) increased fruit bunch weight and significantly reduced the days to flowering of an African Rhino plantain clone. These increases in plant growth and crop yield could be related to greater amounts of soil nutrients and a more stable soil structure promoted by the chicken manure (Figure 1) (Martínez-Rodríguez et al., 2002; Aba et al., 2011; González-Vélez, 2012).

\section{CONCLUSION}

Soil-applied chicken manure improved aggregate stability and soil fertility and increased plant growth and fruit production of dwarf plantain. The increase in AS could be the result of greater microbial activity in chicken manure treated soils. No significant changes were observed in saturated hydraulic conductivity and runoff during selected rain events. However, the amount of sediment in runoff was significantly reduced by plantain leaves placed between rows. Also, leaf cover decreased the soil penetration resistance, a condition that can facilitate root growth.

Chicken manure increased $\mathrm{N}, \mathrm{P}, \mathrm{K}$ and $\mathrm{Mg}$ content in the soil, however $\mathrm{P}$ was above crop sufficiency levels for plantain. It is recommended to reduce the amount of these nutrients applied as fertilizer when chicken manure applications are performed. Additional studies should explore the amount of mineralized phosphate and nitrate from the chicken manure during plantain growth to reduce the need for inorganic fertilizer. Although chicken manure increased the amount of salt and sodium in the soil, these were still within normal levels. In highly weathered soils like Dagüey, under udic moisture regime the significant increases in soil salinity due to chicken manure application are not expected to cause plant growth problems. Nevertheless, chicken manure could potentially increase salts to undesirable levels 
for plantain growth in soils with restricted drainage, and insufficient rainwater and/or irrigation water.

Chicken manure increased plant growth and yield, increasing the weight of bunch and the number of hands per bunch. Also, chicken manure reduced the time to flowering and fruit development. The increase in plantain growth and crop production are attributed to improved soil fertility and soil structure. The combination of chicken manure application and leaf cover from deleafing benefits plantain growth in highly weathered soils by increasing soil nutrient content, stabilizing soil structure and protecting the soil against erosion.

\section{LITERATURE CITED}

Aba, S.C., P.K. Baiyeri and A. Tenkouano. 2011. Impact of poultry manure on growth behavior, black sigatoka disease response and yield attributes of two plantains (Musa spp. AAB) genotypes. Tropicultura 29(1): 20-27.

Beinroth F.H, 1982. Some highly weathered soils of Puerto Rico, 1. Morphology, formation and classification. Geoderma 27: 1-73.

Beinroth F.H., R.J. Engel, J.L. Lugo, C.L. Santiago, S. Ríos and G.R. Brannon, 2003. Updated Taxonomic Classification of the Soils of Puerto Rico, 2002. Bulletin 303, Agricultural Experiment Station, San Juan, PR.

Bertsch, P.M. and P.R. Bloom, 1996. Aluminum: pp 517-550, In: Sparks (ed), Methods of Soil Analysis Part 3 - Chemical Methods. D.L. Soil Science Society of America Book Series: 5 , Madison, WI.

Bonnet, J.A, 1960. Edafología de suelos salinos y sódicos. Estacion Experimental Agrícola, Universidad de Puerto Rico. Río Piedras, Puerto Rico.

Brady, N.C. and R.R. Weil, 2010. Elements of the nature and properties of soil 3 rd. Pearson, Prentice Hall. NJ, USA.

Bray, R.H. and L.T. Kurtz, 1945. Determination of total, organic, and available forms of phosphorus in soils. Soil Science 59: 39-45.

Cattan, P., Y.-M. Cabidoche, J.-G. Lacas and M. Voltz, 2006. Effects of tillage and mulching on runoff under banana (Musa spp.) on a tropical Andosol. Soil and Tillage Research 86: $38-51$.

Clark, Z.F, 2009. Census of Agriculture 2007, Puerto Rico, Island and Municipio Data. National Agricultural Statistics Service-USDA. Geographic Area Series vol. 1, part 52.

Consentino, D., C. Chenu and Y.L. Bissonnais, 2006. Aggregate stability and microbial community dynamics under drying-wetting cycles in a silt loam soil. Soil Biology and Biochemistry 38(8): 2053-2062.

de Souza, C.R., A.K. Ghosh, I. Rebeiro da Silva, E. Santiago de Alvarenga, R. Ferreira Novais and G.L. de Jesus, 2011. Phosphorus transformation in poultry litter and litter-treated Oxisol of Brazil assessed by ${ }^{31} \mathrm{P}-\mathrm{NMR}$ and wet chemical fractionation. R.Bras. Ci. Solo 36: 1516-1527.

Draye, X, 2002. Banana roots: architecture and genetics: pp 399-423, In:Y.Waisel, A. Esthel, T. Beeckman, and U. Kafkafi (eds), Plant Roots: The Hidden Half, $3^{\text {rd }}$ ed, Marcel Dekker Inc., New York, NY. 1,749 pp.

Estación Experimental Agrícola, 1995. Conjunto Tecnológico para la Producción de Plátanos y Guineos. Estación Experimental Agrícola, edición 97.

Ferreras, L., E. Gómez, S. Toresani, I. Firpo and R. Rotondo, 2006. Effect of organic amendments on some physical, chemical, and biological properties in a horticultural soil. Bioresource Technology 97: 635-640.

Gee G.W. and D. Or, 2002. Particle Size Analysis: pp 255-294, In: J.H. Dane and G.C. Topp (eds) Methods of soil analysis. Part 4. 1st ed. ASA and SSSA, Madison, WI. 
González-Vélez, A., 2014. Comportamiento de los clones de plátano Maricongo y FHIA-21 en presencia de Sigatoka negra en la zona de la altura húmeda en Puerto Rico J. Agric. Univ. P.R. 98(1): 21-30.

González-Vélez, A., 2012. Comportamiento del plátano cuerno de Alce (Musa AAB) utilizando gallinaza como enmienda al suelo y nematicidas. J. Agric. Univ. P.R. 96(3-4): 139-153.

González-Vélez, A., 2011. Gallinaza como enmienda al suelo: Efecto en el rendimiento y análisis foliar de yautía, y en las propiedades químicas del suelo. J. Agric. Univ. P.R. 95(3-4): 211-221.

Grossman, R.B. and T.G. Reinsch, 2002. Bulk density and linear extensibility: pp 201-210, In: J.H. Dane and G.C. Topp (eds) Methods of soil analysis. Part 4. 1st ed. ASA and SSSA, Madison, WI.

Hillel, D., 2004. Introduction to Environmental Soil Physics. Elsevier, Academic Press. USA.

Littell, R.C., P.R. Henry and C.B. Ammerman. 1998. Statistical analysis of repeated measures data using SAS procedures. J. Anim. Sci. 76: 1216-1231.

Lowery, B. G.L. Hart, J.M. Bradford, K-J.S. Kung and C. Huang, 1998. Erosion impact on soil quality and properties and model estimates of leaching potential: pp 75-91, In: Soil Quality and Soil Erosion, R. Lal (ed). Soil and Water Conservation Society, USA.

Lowery, B. and J.E. Jr. Morrison, 2002. Soil Penetrometers and Penetrability: pp 363-388, In: J.H. Dane and G.C. Topp (eds) Methods of Soil Analysis. Part 4. 1st ed. ASA and SSSA, Madison, WI.

Lugo-López, M.A., F. Abruña and R. Pérez-Escolar, 1981. The role of crop and industrial residues on erosion control, properties and productivity of some major soils of Puerto Rico. Agricultural Experiment Station (UPR-Mayagüez) No. 266, Río Piedras, PR.

Lugo-Mercado, H.M., J. Badillo-Feliciano and J. López-García, 1978. Effect of soil compaction on tanier yields. J. Agric. Univ. P.R. 62(1): 56-63.

Marín, D.H., R.A. Romero, M. Guzmán and T.B. Sutton, 2003. Black sigatoka: An increasing threat to banana cultivation. Plant Disease 87(3): 208-222.

Marín-Spiotta, E., R. Ostertag and W.L. Silver, 2007. Long-term patterns in tropical reforestation: Plant community composition and aboveground biomass accumulation. Ecological Applications 17(3): 828-839.

Martínez-Rodríguez, G.A., R. Machiavelli and M.A. Vázquez, 2010a. Evaluation of best management practices to reduce nutrient contaminant losses in runoff from broiler litter amended soils. I. Alum additions. J. Agric. Univ. P.R. 94(1-2): 41-60.

Martínez-Rodríguez, G.A., R. Machiavelli and M.A. Vázquez, 2010b. Evaluation of best management practices to reduce nutrient contaminant losses in runoff from broiler litter amended soils. II. Grass cover. J. Agric. Univ. P.R. 94(1-2): 41-60.

Martínez-Rodríguez, G.A., V.A. Snyder, M.A. Vázquez, A. González-Vélez and J.L. Guzmán, 2002. Factors affecting magnesium availability to plantains in highly weathered soils. J. Agric. Univ. P.R. 86(1-2): 1-13.

Muñoz, M.A. and U. Chardón-Alcázar, 2012. Broiler litter applications and chemical properties of highly weathered soils. J. Agric. Univ. P.R. 96(3-4): 129-138.

Muñoz, M.A., O. Colberg and J.A. Dumas, 1990. Chicken manure as an organic fertilizer. J. Agric. Univ. P.R. 74(2): 139-144.

Nelson, D.W. and L.E. Sommers, 1996. Total carbon, organic carbon, and organic matter: pp 961-1010, In: Methods of Soil Analysis Part 3 - Chemical Methods. D.L. Sparks (ed) Soil Science Society of America Book Series:5., Madison, WI.

Nimmo, J.R. and K.S. Perkins, 2002. Aggregate stability and size distribution: pp 317-328, In: J.H. Dane and G.C. Topp (eds) Methods of Soil Analysis. Part 4. 1st ed. ASA and SSSA, Madison, WI.

O’Hallorans, J.M., M.A. Muñoz and O. Colberg, 1993. Effect of chicken manure on chemical properties of a Mollisol and tomato production. J. Agric. Univ. P.R. 77(3-4): 181-191.

O'Hallorans, J.M., M.A. Muñoz and P.E. Márquez, 1997. Chicken manure as an amendment to correct soil acidity and fertility. J. Agric. Univ. P.R. 81(1-2): 1-8.

Ortega-Achury, S.L., G.A. Martínez, D. Sotomayor-Ramírez and M.A. Muñoz-Muñoz, 2007. Nutrient concentrations in runoff from different manure amended fields of the tropics under natural rainfall conditions. J. Agric. Univ. P.R. 91(3-4): 101-115. 
Ortiz-Escobar, M.E. and N.V. Hue, 2008. Temporal changes of selected chemical properties in three manure-amended soils of Hawaii. Bioresource Technology 99: 8649-8654.

Pagán-Roig, I.C., J.A. Chong, J.A. Dumas and C. Estévez de Jensen, 2016. Repeated short-term organic amendments effects on physical and biological properties of a San Antón soil. J. Agric. Univ. P.R. 100(2): 123-140.

Pérez-Escolar, R. and J.S. Ortiz-Vélez, 1979. Salinity effects on sugarcane germination, growth, and root development. J. Agric. Univ. P.R. 51(3): 377-385.

Piccolo, A., G. Pietramellara and J.S.C. Mbawu, 1997. Use of humic substances as soil conditioners to increase aggregate stability. Geoderma 75: 267-277.

Reynolds, W.D. and D.E. Elrick, 2002. Constant head well permeameter (Vadose Zone): pp 844-858, In: Methods of Soil Analysis Part 4. Soil Science Society of America, Madison, WI.

Robinson, J.C. and V. Galán-Saúco, 2010. Site selection, soil requirements, and soil preparation: pp 115-124, In: J.C. Robinson and V. Galán Saúco (editors), Bananas and Plantains, $2^{\text {nd }}$ ed. CAB International.

Rosales, FE., LE. Pocasangre, J. Trejos, E. Serrano and W. Peña, 2008. Guía de diagnóstico de la calidad y salud de suelos bananeros. Bioversity International. Roma, Italia.

SAS Institute Inc., 2013. The MIXED Procedure. In SAS/STAT ${ }^{\circledR} 13.1$ user's guide. SAS Institute Inc., Cary, NC.

Scotti, R., G. Bonanomi, R. Scelza, A. Zoina and M.A. Rao, 2015. Organic amendments as sustainable tool to recovery fertility in intensive agricultural systems. Journal of Soil Science and Plant Nutrition 15(2): 333-352.

Six, J., H. Bossuyt, S. Degryze and K. Denef, 2004. A history of research on the link between (micro)aggregates, soil biota, and soil organic matter dynamics. Soil and Tillage Research 79: 7-31.

Snyder, V.A., R. Pietri-Oms, M. Miro and H.M. Lugo, 1993. Structural stability, pore size distribution and surface charge properties of clay soils with varying mineralogy and organic matter content. J. Agric. Univ. P.R. 77(1-2): 11-31.

Soil Survey Staff, Natural Resources Conservation Service, United States Department of Agriculture. Official Soil Series Descriptions, 2018. Available online at https://soilseries.sc.egov.usda.gov/OSD_Docs/D/DAGUEY.html. Accessed [07/19/2018].

Sotomayor-Ramírez, D. and G.A. Martínez, 2006. The status of phosphorus and other fertility parameters in soils of Puerto Rico. J. Agric. Univ. P.R. 90(3-4): 145-157.

Sotomayor-Ramírez, D., G.A. Martínez, Pérez-Alegría and J. Ramírez-Ávila, 2006. Off-field transport of phosphorus from and Ultisol under pasture. J. Agric. Univ. P.R. 90(3-4): 159-172.

Sotomayor-Ramírez, D., G.A. Martínez, J. Ramírez-Ávila and E. Más, 2008. Effectiveness of grass filter strips for runoff nutrient and sediment reduction in dairy sludge-amended pastures. J. Agric. Univ. P.R. 92(1-2): 1-14.

Sotomayor-Ramírez, D., E. Román-Paoli, L.E. Rivera, Y. Li and P.J. Stoffella, 2010. Tomato (Solanum lycopersicum L.) response to fertilizer nitrogen and compost. J. Agric. Univ. P.R. 94(1-2): 79-103.

Sumner, M.E. and W.P. Miller, 1996. Cation exchange capacity and exchange coefficients. pp. 1201-1230, In Methods of Soil Analysis Part 3 - Chemical Methods. D.L. Sparks editor. Soil Science Society of America Book Series:5., Madison, WI.

Thomas, G.W., 1996. Soil pH and soil acidity. pp. 475-490, In Methods of Soil Analysis Part 3 - Chemical Methods. D.L. Sparks (editor). Soil Science Society of America Book Series:5., Madison, WI..

Wendt, K., 1995. Determination of nitrate/nitrite in surface and wastewaters by flow injection analysis. QuickChem Method 10-107-04-1-A, revised by A. Sardina in 28 August, 2000. Lachat Instruments, Inc. Milwaukee, WI.

Wright, R.J. and T.I. Stuczynski, 1996. Atomic absorption and flame emission spectrometry. pp 65-90, In Methods of Soil Analysis Part 3 - Chemical Methods. D.L. Sparks editor. Soil Science Society of America Book Series:5., Madison, WI. 